\title{
Technology Management of Capital Assets and Risks in the Service Sharing Economy: Cases of Uberization of Crowdfunding and Transportation in Mexico*
}

\author{
Leonel Corona-Treviño \\ National Autonomous University of Mexico, Mexico City, Mexico
}

\begin{abstract}
Firms such as Airbnb, Uber, Blablacar have platforms for connecting owners of underused assets with clients through, the internet, thus allowing people to rent out their spare rooms, or book relay rides by acting as matchmakers, allocating resources where they are needed and charging a percentage of the cost in return. This phenomenon could be regarded from the point of view: (1) of Internet technology evolution from a network of computers to a network of people devoted to sharing their knowledge and user experience, coming further, as the Internet of Things (IoT), and (2) as part of the increasing involvement of the user (consumer/client) in production and innovation processes. These approaches allow us to analyze service-user platform firms according to the different kinds of specific assets distribution and risks. The new organization is based on internet platform tools which integrate information, machinery, energy, and science, and costumer collaboration. We conclude that there are large profits for those firms based on platforms, as there are not yet any counterbalances through competition, posing the question about the needed or not of technology management regulation during this phase of service sharing economy. A selection of 17 service platform firms in Mexico involved in transportation and crowdfunding are described on the basis of their business model, the market and the distribution of assets and income.
\end{abstract}

Keywords: platform firms, concentration of income, uberization, service economy, sharing economy, crowdfunding, Mexico

\section{Introduction}

The objective of this paper is to propose an economic approach to look at services which are linked through a TIC Platform which is the marketplace that connects app developers and iPhone owners (Van Alstyne, Parker, \& Choudary, 2016).

Thus, a specific platform matches both the participation of the producer of the service to the customer.

From this point of view, the aim is to characterize the relationships between users (customer/client) and providers within production, looking mainly at (1) the diminishing of costs and transaction costs, and externalities (network effects), (2) the distribution of capital assets, and (3) the concentration-distribution of incomes.

\footnotetext{
* This paper is part of the research on entrepreneurship sponsor by Papiit IN305317 UNAM.

Leonel Corona-Treviño, Ph.D., professor, Faculty of Economics, National Autonomous University of Mexico (UNAM), Mexico City, Mexico.

Correspondence concerning this article should be addressed to Leonel Corona-Treviño, Cepcyt FE-UNAM, Ciudad Universitaria, Cd. de Mexico 04510, Mexico.
} 
A selection of 17 service platform firms in Mexico are described based on their business model, the market and the distribution of assets and income. The aim is to qualify the social and economic impact of these firms as well as the possibilities of sustainability and growth. The purpose of this paper is to set out a perspective of the distribution of revenue versus its concentration in the platform firms.

\section{Literature Review}

Platform firms providing online services enable people to share underused assets such as cars, accommodation, bicycles, household appliances, and other items with others willing to pay to use them. The result is known variously as "collaborative consumption", the "collaborative economy", "peer economy", “access economy”, or "sharing economy".

This new way of producing services through the platform represents a fundamental shift in organizational market structures made possible by advances in information technology and communications (ICT).

As part of ICT, the most significant moments of recent Internet evolution are (Solima, Della Peruta, \& Del Giudice, 2016):

- 1983 - Internet is defined by one-way and a relatively low number of content generators, the flow of information activated by the producer to support and direct the choice of a potential buyer.

- 2003-Establishment of Web 2.0 and social media allowing a multiple two-way communications process: Producer's comments, user experiences and the opinions and observations of third parties could now be accessed online.

- 2008-IoT, where information generators expand further in multidirectional communication. Smart objects, therefore, not only are the object of communication, but also take on the role of protagonist, becoming capable of imparting their name, their position, and a whole series of data in relation to the environment in which they find themselves.

These technological changes are managed by the platforms firms in parallel with an evolutionary process which began (1) as the direct relationship between a simple list of posts with requests or provided information on services available and services demanded (Manjoo, 2016); (2) using internet as a way to demand and generate a system service; (3) the disruptive platform revolution that has transformed Business to Customers (B2C) into digital newcomers who are matching Customer to Customer (C2C or P2P-Peer to Peer) networks that have built successful businesses such as AirBnB in hotels, Uber in taxis.

Peer economy systems work by exploiting slack capacity in privately owned goods, changing the way of management in three main aspects (Van Alstyne, Parker, \& Choudary, 2016):

- From resource control to resource orchestration: The shift is from controlling scarce and valuable assets (equipment, real estate and intangible assets like intellectual property) to assets coming from the community and the resources of its members own and contribute; they are rooms or cars or ideas and information, that is the network of producers and consumers is the main asset, which is hard to copy.

- From internal production to external interaction: Traditional firms organize their labor and resources to create value participating in an entire chain of product activities, from materials sourcing to sales and service. Meanwhile, platform firms create value by facilitating interactions between external producers and consumers.

- From a focus on customer value to a focus on ecosystem value: Value centered on individual customers of

\footnotetext{
1 “The Sharing economy”, The economist Technology Quarterly, 9th Mar., 2013.
} 
products and services moves to the platform dealing with the total value of an expanding ecosystem in a circular, iterative, feedback-driven process.

These new orientations in technology management are deployed in systems like Uber and Airbnb; it is sometimes referred as "Uberization", meaning that instead of taxi companies used to transport passengers, Uber just connects drivers with passengers; and Airbnb instead of having hotels to offer hospitality services, just connects hosts with guests. And this list goes on as even Amazon connects booksellers with buyers of used books (Morozov, 2015).

However, there are other views in which "Uber is the exception, not the norm. Uber, but for Uber-and not much else” (Manjoo, 2016). The Uber model fits relatively few sectors or there are virtually no other major industries where those same characteristics apply to customer experience; high and regulated prices; monopolistic markets; huge numbers of daily users; lack of viable alternatives (Tullman, 2016).

There are some other industries that have already been "uberized” (Thrasyvoulou, 2015):

(1) Housing, renting, or purchasing a property is a long and hard process of getting information about the options. So, real estate is changing to process online, using digital platforms to bypass the transaction costs of the real estate broker (and their fees) to contact the renter directly.

(2) Automotive Re-Selling, traditionally a face-to-face industry, buying a used car-from negotiating prices, dealing with a salesman, getting the right information, and doing the paperwork. A platform solves many of the inherent issues in the used car market by buying a used car doing a full 185-point inspection, guarantees the quality of the cars listed (Ex. Beepi).

(3) Personalized Tasks: Some people have a second income performing freelancing services. Companies are also taking advantage of this trend- "SMBs" can hire with great flexibility and "on demand" through digital marketplaces. Services like "Contently" for writing, "Rev" for transcription, and "Super Tasker" for editing are examples of such P2P marketplaces.

(4) Mobile Wireless could come into a P2P service. Due to technology, we now know where Wi-Fi is most used (metropolitan cities vs. rural suburbs) and where it is most needed (corporate parks at lunchtime). In a demand-generated setting, Wi-Fi services can be concentrated in needed areas and given to those who need it most, for an appropriate price based on willingness and need.

(5) Financial Services can use a P2P marketplace based on collected data points from the user as well as assessment criteria from the lending people (risk, amount, overhead) to determine feasibility.

\section{Methodology}

The platform firms can be located in the intersection of two tendencies: (1) the convergences of technology and knowledge services, and (2) the increasing involvement of the user (consumer/client) in the production and the innovation processes.

First considering the dynamics of technology the emerging integrated approach, the interrelationship between technology and services innovations is becoming more important (Omachonu \& Einspruch, 2014). As a matter of fact there are four convergences, one of Technology (Kodama, 2014), another of service knowledge, and two interrelated tendencies: technology-enabled services and product-service system (PSS).

These four convergences tendencies are related in different a specific ways to the platform firms depending mainly of the user participation. Services increase their heterogeneity depending on the extent of customer interaction (Randhawa \& Scerri, 2014). The innovation strategies are changing from "innovating for 
customers" to "innovating with customers" and involving those customers in a process of "knowledge co-creation” (Desouza, Awazu, Jha, Dombrowski, Papagari, Baloh, \& Kim, 2008).

Besides this user, participation is the growing of the sharing economy which is gaining ground, fundamentally altering how people own and consume which are divided into three main types (Botsman \& Rogers, 2010): (1) Product service systems, which allow members to share multiple products that are owned by companies or by private persons, like car-sharing services (Zipcar P2P acquired by Avis; Zilok.com), (2) Redistribution markets: P2P matching or social networks allow the re-ownership of a product (NeighborGoods.com and thredUP.com, (3) Collaborative lifestyles in which people share similar interests and help each other mostly enabled through digital technology.

Companies can respond to the rise of collaborative consumption by: (1) selling use of a product rather than ownership, (2) supporting customers in their desire to resell goods, (3) exploiting unused resources and capacities, (4) providing repair and maintenance services, (5) using collaborative consumption to target new customers, and (6) developing entirely new business models enabled by collaborative consumption (Matzler, Veider, \& Kathan, 2015). However, the main asset that the firms are receiving from the collaborative economy is the network effect (or network externality).

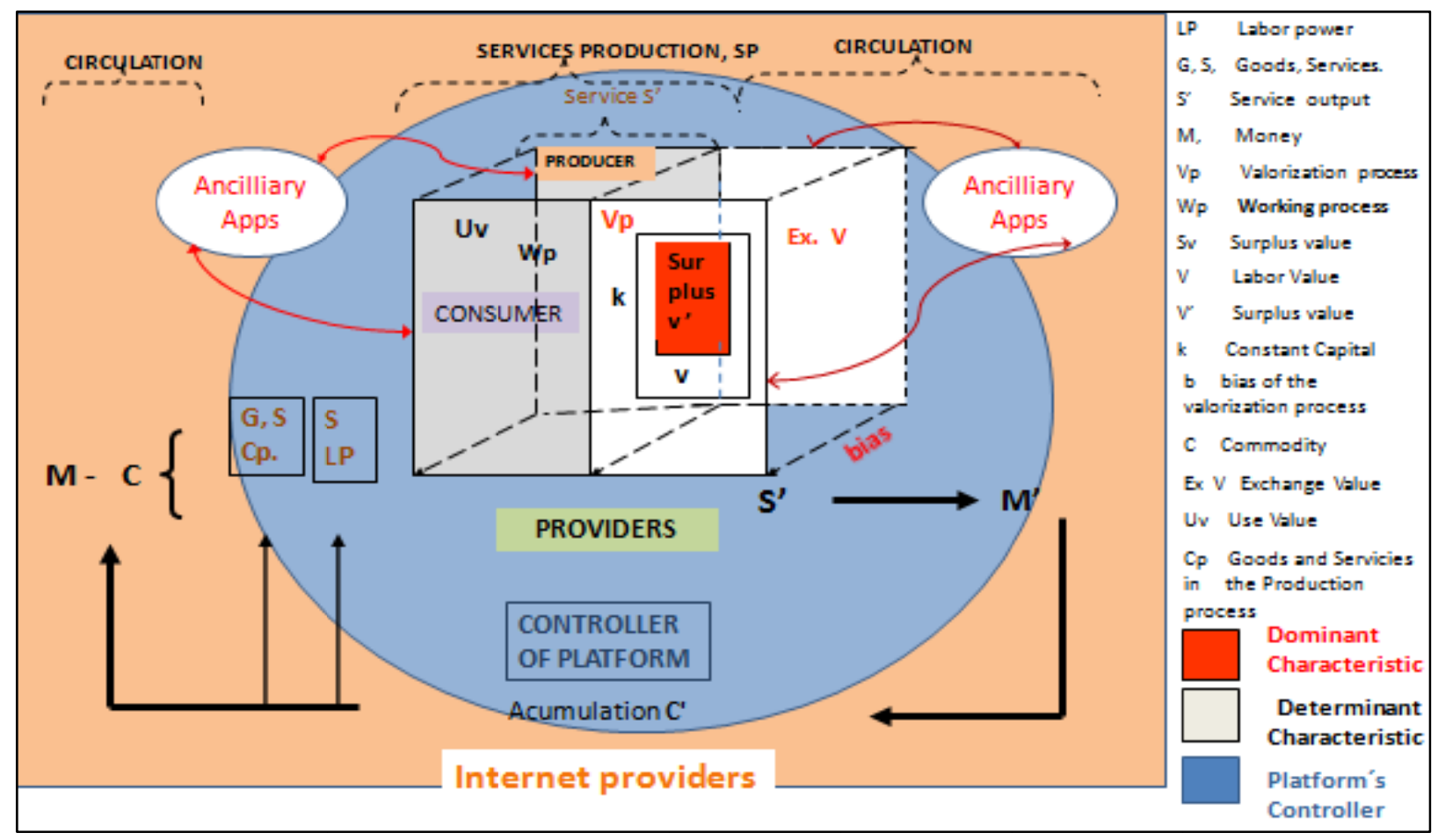

Figure 1. Service platform firms-flow of value and resources. Source: Author elaboration.

The value of a product or service depends on how many other users there are, therefore is a "demand-side economies of scale" (Shapiro \& Varian, 1999).

The capital flow for Platform Firms put into play the following components: (1) the internet operators, (2) the platform which control the rules of the service's actors (governance), (3) the providers of the service trough the App, (4) producer and consumer who enter into a relationship organized by the platform, (5) the inputs of production, and (6) other ancillary Apps (GPS, Electronic payment, etc.) (Figure 1). 
The service with the platform firm operates in two inherent process: (1) production of the service using the inputs (goods, G, and services, S), and labor power, Lp; both related in a working process, Wp, to generate a service with user value (Uv) to the consumer, (2) the valorization process in which those inputs ( $\mathrm{k}$, for the used capital, Cp) and Labor Value (V) are paid by the user (Exchange value, Ex. V) through the price of the service (S'); which includes a margin (surplus value, v').

It is argue that (hypothesis) the platform firms, have an initiating phase with large distribution of benefits, however, if they grow and reach a consolidated phase, profits are mainly accumulated by the platform controller (Uber firm). The template is used to format your paper and style the text. All margins, column widths, line spaces, and text fonts are prescribed; please do not alter them. You may note peculiarities. For example, the head margin in this template measures proportionately more than is customary. This measurement and others are deliberate, using specifications that anticipate your paper as one part of the entire proceedings, and not as an independent document. Please do not revise any of the current designations.

\section{Results}

Applying the scheme (Figure 1) of the platform firm to Uber, the following analysis can be made:

The platform firm (Uber) is allowed to relate a consumer specific demand (transportation need) with the service producer offer (Uber Car available which is located nearest to the customer). After a protocol identification of the driver with the client-through the Mobil Uber App information-the working production of the service transportation begins and ends with the arrival of the client to its destination point (Wp). Then the valorization of it occurs with a payment exchange made automatically by the platform to the client's credit card (Exchange Value, Ex. V). The price has to be sufficient to pay the drivers fees (Value, V) and the use of capital (the operation costs and the depreciation of the car, k) plus profits (surplus value), that is the valorization process (Vp) (Figure 1).

\section{Analysis of Mexico PF Cases}

In transportation and crowdfunding industries, it has been selected 17 Platform Firms, PF, to analyze some of the variables mentioned before (Tables 1 and 2).

- Business Model

In the transportation industries (Table 1), there are properly five PF business models (Table 1a) and two kind of sharing economy models (PF 6, 7, Table 1b). The PF 8 is not a plain platform; it is more an e-commerce rent car.

In the crowdfunding industry (Table 2), the business model is oriented to P2P (PF 1, 7), to entrepreneurship (PF 2, 4, 6), real estate projects (PF 5, 8) and one financing based on factoring (PF 9).

- Distribution of Income

For the transportation firms, the service charge for each trip is an important share of the total income: from 25\% in Uber, 15\% Easy Taxi, 10\% Avant, down to 6\% Yaxi (Table 1a). Therefore, these PFs are concentrating a large part of the total income compare with its costs. This is a result of the level of monopolization of the firm.

\section{- Assets}

For the transportation industry, the main capital assets are the value of the cars register on the platform, which are owned by the driver or by a private investor who takes charge of operating and depreciation costs. 
Therefore, the model allows a large distribution of benefits which are discovered and put it into play through a web application, with the objective to be used in a large scale. The capital is obtained from "idle social capacity", as it is based on non-used assets, or by investing buying a car with credit. This means that the assets are put as capital by its owners (car-Ubers case). Peer economy systems like Uber and Airbnb work by exploiting slack capacity in privately owned goods.

Crowd-funding through the firm's platform connects people who need a loan ( $\mathrm{PF} 1$, 7), with people looking for investment opportunities either in entrepreneurship (PF 2, 4, 6), real estate (PF 5, 8) or factoring (PF 9). The social impact is important for SME as it is opening a new way for funding projects (initial phase, see hypothesis).

\section{- Labor Porosity}

Mexico's social economic conditions are such that there are many economically active people without a full employment (porosity of labor time). Therefore, they can work in a PF with flexible time and they have the required skills (particularly for Uber). The drivers with their owned car or without one are students, retired workers, part-time workers, or unemployed. As a result, the metropolitan cities can provide easily offer working time demanded by the PF, providing an opportunity for full or part-time employment.

- Regulation

In transport, the PFs compete with the existing conventional taxi services, which are quite highly regulated and require a taxi permit which is difficult to obtain and demand fulfilling a number of formalities. Thus, the PFs control the rules for registering these private cars which, with lower transaction costs offer transportation services.

Instead of adhering to a precise and rigorous code that spells out the rights of customers and the obligations of service providers...platform operators rely on the widely distributed knowledge of participants in a service, hoping that the market will eventually punish those who misbehave. (Morozov, 2015)

The lower regulated of the platform operation is favorable to achieve a "higher sales volume than their competitors, have a lower average cost of doing business, allowing them to reduce prices, which increases volume further, which permits more price cuts—a virtuous feedback loop that produces monopolies" (Van Alstyne, Parker, \& Choudary, 2016). This positive impact is when the PF reached a "critical mass", the network effects of operating a service that becomes more valuable as more people join it. The PF is disrupting any economic activity through the use of technology "to circumvent unnecessary bureaucracy and legislation" (Glance, 2015).

Dealing with crowd-funding, "Mexico will soon enact an updated securities regulatory regime to embrace internet finance” (Crowdfundinsider, 2016).

- Transaction Cost, TC

The TCs are decreasing with the use of the platform for the producer and for de client. But when the service demand is going up, the platform uses dynamic prices which are informed to the client shifting the extra money to the producer and the platform.

- Quality

The platform's rules for the service producer allow a better quality of the physical conditions of the cars. The means of payment for the service which is charged to a card is easy and better for the client, but not for the drives as they only get their share of the income at the end of the week. 
Table $1 \mathrm{~A}$

Mexico: Transportation Platform Firms: Business Model, Market and Capital

\begin{tabular}{|c|c|c|c|c|c|c|c|}
\hline $\begin{array}{l}\text { Transportation } \\
\text { firm }\end{array}$ & Firm & Business model & $\begin{array}{l}\text { The platform intermediation (algoríthm, system, } \\
\text { technology) }\end{array}$ & & Market & $\begin{array}{l}\text { Who contributes the } \\
\text { capital and takes the } \\
\text { risks }\end{array}$ & $\begin{array}{l}\text { Fees and } \\
\text { charges }\end{array}$ \\
\hline 1 & Uber & $\begin{array}{l}\text { Uber is a location-based } \\
\text { app that provides hiring a } \\
\text { private driver on-demand. }\end{array}$ & $\begin{array}{l}\text { Platform connect a private driver holding driving } \\
\text { licence to someone who has a specific transport } \\
\text { demand. This is done using data devices: mapping } \\
\text { data; register and identification of cars and drivers } \\
\text { as well as passangers who have a smartphone. } \\
\text { New payment systems are used to make } \\
\text { transactions smoother; geolocational sensors } \\
\text { which traces the location and the trajectory of the } \\
\text { ride in real time. }\end{array}$ & $\begin{array}{l}\text { Private } \\
\text { driver }\end{array}$ & Passenger & $\begin{array}{l}\text { Assests are the private } \\
\text { cars register in the } \\
\text { platform. The risks } \\
\text { diminished trough } \\
\text { rules related } \\
\text { registration either as a } \\
\text { driver or as a pasanger. }\end{array}$ & $\begin{array}{l}25 \% \text { of the } \\
\text { ride cost }\end{array}$ \\
\hline 2 & Cabify & $\begin{array}{l}\text { Private transport service } \\
\text { operated on a platform. }\end{array}$ & $\begin{array}{l}\text { Based on passanger demand the platform selects } \\
\text { the driver-car through location system, route } \\
\text { setting and rate calculation. }\end{array}$ & Drivers & $\begin{array}{l}\text { People looking } \\
\text { for private } \\
\text { transportation } \\
\text { alternatives } \\
\end{array}$ & \multirow{4}{*}{$\begin{array}{l}\text { The capital is provided } \\
\text { by the private driver } \\
\text { - who takes charge of } \\
\text { operating and } \\
\text { depretiation costs. }\end{array}$} & $\begin{array}{l}\text { Fees as \% of } \\
\text { each travel } \\
\text { price }\end{array}$ \\
\hline 3 & $\begin{array}{l}\text { Avant } \\
\text { (Mexican } \\
\text { Uber) } \\
\end{array}$ & $\begin{array}{l}\text { Private transport model, } \\
\text { connects drivers and } \\
\text { passengers. }\end{array}$ & $\begin{array}{l}\text { Taxi service is requested through an app. This } \\
\text { allows to put in contact to coductores and } \\
\text { passengers. }\end{array}$ & $\begin{array}{l}\text { Private car } \\
\text { cunductors }\end{array}$ & Passenger & & $\begin{array}{l}\text { Fees } 10 \% \text { of } \\
\text { commision }\end{array}$ \\
\hline 4 & Yaxi & $\begin{array}{l}\text { Private transport model, } \\
\text { connects drivers and } \\
\text { passengers. }\end{array}$ & $\begin{array}{l}\text { It acts as an intermediary between passengers and } \\
\text { taxi drivers through the company's website or } \\
\text { with the mobile application. }\end{array}$ & $\begin{array}{l}\text { Taxi } \\
\text { drivers }\end{array}$ & Passenger & & $\begin{array}{l}\text { Fees } 6 \% \text { of } \\
\text { commision }\end{array}$ \\
\hline 5 & Easy Taxi & $\begin{array}{l}\text { Private transport model, } \\
\text { connects drivers and } \\
\text { passengers. }\end{array}$ & $\begin{array}{l}\text { It acts as an intermediary between passengers and } \\
\text { taxi drivers through the company's website or } \\
\text { with the mobile application. }\end{array}$ & $\begin{array}{l}\text { Taxi } \\
\text { drivers }\end{array}$ & Passenger & & $\begin{array}{l}\text { Fees } 15 \% \text { of } \\
\text { commision }\end{array}$ \\
\hline
\end{tabular}

Source: Author elaboration based on firms' web pages. The author would like to thanks Maricarmen Moreno and Diego López of Cepcyt-UNAM for their assistance on this table. 
Table 1B

Mexico: Transportation Platform Firms: Business Model, Market and Capital

\begin{tabular}{|c|c|c|c|c|c|c|c|c|}
\hline $\begin{array}{l}\text { Transportation } \\
\text { firm }\end{array}$ & Firm & Business model & $\begin{array}{l}\text { The platform intermediation } \\
\text { (algoríthm, system, } \\
\text { technology) }\end{array}$ & & Market & $\begin{array}{l}\text { Who contributes the } \\
\text { capital and takes the } \\
\text { risks }\end{array}$ & Fees and charges & \\
\hline 6 & $\begin{array}{l}\text { Aventones. } \\
\text { com( Purcha } \\
\text { sed by Bla } \\
\text { Bla Car) }\end{array}$ & $\begin{array}{l}\text { Private cars that make } \\
\text { pre-established routes } \\
\text { between cities and publish } \\
\text { them on the platform } \\
\text { offering the seats. }\end{array}$ & $\begin{array}{l}\text { The platform locates } \\
\text { geographically the routes } \\
\text { that the provider registers } \\
\text { and publishes them so that } \\
\text { register consumers book a } \\
\text { whole or partial trip. }\end{array}$ & $\begin{array}{l}\text { Private car } \\
\text { drivers }\end{array}$ & $\begin{array}{l}\text { Users looking } \\
\text { for economic } \\
\text { sharing } \\
\text { transportation } \\
\text { alternatives. }\end{array}$ & $\begin{array}{l}\text { The capital is povider } \\
\text { by the private driver } \\
\text { cars who takes charge } \\
\text { of operating and } \\
\text { depretiation costs. }\end{array}$ & $\begin{array}{l}\text { During introduction of } \\
\text { the App there is no } \\
\text { commision ( } 9-12 \% \text { of } \\
\text { the trip cost in developed } \\
\text { countries). }\end{array}$ & 0 \\
\hline 7 & $\begin{array}{l}\text { Bla Bla Car } \\
\text { México, } \\
\text { COMUTO } \\
\text { SA }\end{array}$ & $\begin{array}{l}\text { Private cars that make } \\
\text { pre-established routes } \\
\text { between cities and publish } \\
\text { them on the platform } \\
\text { offering the seats. }\end{array}$ & $\begin{array}{l}\text { The platform locates } \\
\text { geographically the routes } \\
\text { that the conductors publish } \\
\text { with their available seats. } \\
\text { Passengers seek a trip and } \\
\text { choose the driver. Travel } \\
\text { together and everyone saves } \\
\text { money. }\end{array}$ & $\begin{array}{l}\text { Private car } \\
\text { cunductors }\end{array}$ & $\begin{array}{l}\text { Users looking } \\
\text { for economic } \\
\text { sharing } \\
\text { transportation } \\
\text { alternatives. }\end{array}$ & $\begin{array}{l}\text { The capital is povider } \\
\text { by the private driver } \\
\text { cars who takes charge } \\
\text { of operating and } \\
\text { depretiation costs. }\end{array}$ & $\begin{array}{l}\text { During introduction of } \\
\text { the App there is no } \\
\text { commision ( } 9-12 \% \text { of } \\
\text { the trip cost in developed } \\
\text { countries). }\end{array}$ & 0 \\
\hline 8 & $\begin{array}{l}\text { Carrot, } \\
\text { Autos } \\
\text { Compartidos } \\
\text { de México }\end{array}$ & $\begin{array}{l}\text { It is not a full platform: Car } \\
\text { rental per hour, day or week. } \\
\text { They have cars distributed } \\
\text { throughout the city and a } \\
\text { system of "cards" with } \\
\text { which you unlock the car } \\
\text { and you drive it yourself. }\end{array}$ & $\begin{array}{l}\text { The platform locates } \\
\text { geographically the available } \\
\text { vehicles. Simultaneously } \\
\text { allows the user to reserve a } \\
\text { vehicle and with a security } \\
\text { system by magnetic cards } \\
\text { can open and drive the } \\
\text { assigned car. }\end{array}$ & Rental car & $\begin{array}{l}\text { Young and } \\
\text { adults looking } \\
\text { for personal and } \\
\text { private } \\
\text { transportation } \\
\text { alternatives. }\end{array}$ & $\begin{array}{l}\text { Firm's Cars covering } \\
\text { the operation costs and } \\
\text { depreciation of the } \\
\text { cars. }\end{array}$ & $\begin{array}{l}\text { Flexible rates charged to } \\
\text { the user. }\end{array}$ & 1 \\
\hline
\end{tabular}

Source: Author elaboration based on firms' web pages. The author would like to thanks Maricarmen Moreno and Diego López of Cepcyt-UNAM for their assistance on this table. 
Table 2

Mexico: Crowdfunding Platform Firms: Business Model, Market and Capital

\begin{tabular}{|c|c|c|c|c|c|c|c|}
\hline $\begin{array}{l}\text { Crowdfunding } \\
\text { firm }\end{array}$ & Firm & Business model & $\begin{array}{l}\text { The platform intermediation } \\
\text { (algoríthm, system, technology) }\end{array}$ & Ma & arket & $\begin{array}{l}\text { Who contributes } \\
\text { the capital and } \\
\text { takes the risks }\end{array}$ & $\begin{array}{l}\text { Fees and } \\
\text { charges \% of } \\
\text { capital }\end{array}$ \\
\hline 1 & Kubo Financiero & $\begin{array}{l}\text { Crowdfunding and Peer } \\
\text { to Peer (P2P) Lending. }\end{array}$ & $\begin{array}{l}\text { The firm's platform connects people } \\
\text { who need a loan with people looking } \\
\text { for investment opportunities. The } \\
\text { platform orders the investment } \\
\text { projects according to risk/profitability, } \\
\text { so that the investor can create a } \\
\text { diversify portfolio; and the } \\
\text { entrepreneur to obtain financing. }\end{array}$ & $\begin{array}{l}\text { People looking } \\
\text { for investment } \\
\text { opportunities. }\end{array}$ & $\begin{array}{l}\text { People or firms } \\
\text { who need a loan. }\end{array}$ & $\begin{array}{l}\text { Investor. The risk } \\
\text { is shared between } \\
\text { the investor and } \\
\text { the firm. }\end{array}$ & $6.50 \%$ \\
\hline 2 & $\begin{array}{l}\text { Fondeadora } \\
\text { (Fusioned with } \\
\text { Kickstarter) }\end{array}$ & $\begin{array}{l}\text { Crowdfunding for } \\
\text { community Social } \\
\text { Entrepreneurs projects } \\
\text { through Business } \\
\text { Simulators, Mentors, } \\
\text { Campaigns. }\end{array}$ & $\begin{array}{l}\text { Methodology that evaluates and } \\
\text { organizes the creative projects } \\
\text { according to their feasibility with a } \\
\text { deadline and an investor rewards } \\
\text { system. }\end{array}$ & $\begin{array}{l}\text { "Investors" invest } \\
\text { in a project in } \\
\text { exchange of } \\
\text { rewards and to } \\
\text { being part of a } \\
\text { community. }\end{array}$ & $\begin{array}{l}\text { Entrepreneurs } \\
\text { focused on } \\
\text { cultural/creative } \\
\text { activities (art, } \\
\text { cinema, design). }\end{array}$ & $\begin{array}{l}\text { Investor: Capital } \\
\text { risk is low as the } \\
\text { decision to invest } \\
\text { is informed. The } \\
\text { reward for the } \\
\text { amount invested is } \\
\text { known in advance. }\end{array}$ & $2.45 \%$ \\
\hline 3 & Mi Cochinito & $\begin{array}{l}\text { It is not a PF: Teaching } \\
\text { crowdfunding, giving } \\
\text { mentoring, sensitization } \\
\text { Campaigns to Social } \\
\text { Entrepreneurs with their } \\
\text { communities. }\end{array}$ & $\begin{array}{l}\text { Integration of social initiatives with } \\
\text { interested entrepreneurs in the field, } \\
\text { validation of the social impact of the } \\
\text { project and promotion in social } \\
\text { networks. }\end{array}$ & $\begin{array}{l}\text { Investors looking } \\
\text { for social projects } \\
\text { to invest in, in } \\
\text { exchange for } \\
\text { rewards and } \\
\text { joining a } \\
\text { community. }\end{array}$ & $\begin{array}{l}\text { Entrepreneurs } \\
\text { focused on social, } \\
\text { cultural impacts } \\
\text { and creative } \\
\text { endeavors (art, } \\
\text { cinema, design). }\end{array}$ & $\begin{array}{l}\text { Investor: Capital } \\
\text { risk is low as the } \\
\text { decision to invest } \\
\text { is informed. The } \\
\text { reward for the } \\
\text { amount invested is } \\
\text { known in advance. }\end{array}$ & $8.50 \%$ \\
\hline 4 & Play Business & $\begin{array}{l}\text { Financing for } \\
\text { entrepreneurs. }\end{array}$ & $\begin{array}{l}\text { Platform linking investors with } \\
\text { entrepreneurs with a project, how } \\
\text { much money he needs, the percentage } \\
\text { he is willing to pay, and the time it will } \\
\text { take to develop it. If the project is } \\
\text { funded, the investors make the first } \\
\text { payment (deposit). The entrepreneur } \\
\text { must record his project progress on a } \\
\text { monthly basis. }\end{array}$ & $\begin{array}{l}\text { Risk capital } \\
\text { Investors, looking } \\
\text { for projects to } \\
\text { invest in return } \\
\text { for a yield. }\end{array}$ & $\begin{array}{l}\text { Entrepreneurs } \\
\text { looking for } \\
\text { financing. }\end{array}$ & $\begin{array}{l}\text { Risk taken by the } \\
\text { entrepreneur and } \\
\text { the investor. }\end{array}$ & $5 \%$ \\
\hline 5 & Briq Fund & $\begin{array}{l}\text { Briq is an intermediary } \\
\text { to finance Real Estate } \\
\text { projects. }\end{array}$ & $\begin{array}{l}\text { The platform through algorithms } \\
\text { calculates the yields. The investors } \\
\text { can monitor the progress and yields of } \\
\text { each project of the portfolio which are } \\
\text { selected and analyzed by an } \\
\text { investment committee. }\end{array}$ & Investors. & $\begin{array}{l}\text { Real State } \\
\text { Developers. }\end{array}$ & $\begin{array}{l}\text { Investors and Real } \\
\text { State Developers. }\end{array}$ & \\
\hline
\end{tabular}


(Table 2 continued)

\begin{tabular}{|c|c|c|c|c|c|c|}
\hline $\begin{array}{l}\text { Crowdfunding } \\
\text { firm }\end{array}$ & Firm & Business model & $\begin{array}{l}\text { The platform intermediation } \\
\text { (algoríthm, system, technology) }\end{array}$ & Market & $\begin{array}{l}\text { Who contributes } \\
\text { the capital and } \\
\text { takes the risks }\end{array}$ & $\begin{array}{l}\begin{array}{l}\text { Fees and } \\
\text { charges \% of } \\
\text { capital }\end{array} \\
\end{array}$ \\
\hline 6 & $\begin{array}{l}\text { Pitch Bull } \\
\text { Funding }\end{array}$ & $\begin{array}{l}\text { It brings together SMEs } \\
\text { and Entrepreneurs who } \\
\text { need financing for } \\
\text { expansion projects. }\end{array}$ & $\begin{array}{l}\text { It is a platform linking financial } \\
\text { people (persons or financial firms) and } \\
\text { credit applicants for expansion } \\
\text { projects (SMEs and Entrepreneurs). A Investors in } \\
\text { risk analysis is done. An auction is SMEs. } \\
\text { presented to the funders, those with } \\
\text { the lowest rate is the one chosen by the } \\
\text { system. }\end{array}$ & $\begin{array}{l}\text { SMEs with } \\
\text { financing projects } \\
\text { needs. }\end{array}$ & $\begin{array}{l}\text { Investors and Real } \\
\text { State Developers. }\end{array}$ & $1 \%$ \\
\hline 7 & $\begin{array}{l}\text { Prestadero, } \\
\text { Communitas } \\
\text { Aurum }\end{array}$ & $\begin{array}{l}\text { Loans and credit through } \\
\text { a platform. }\end{array}$ & $\begin{array}{l}\text { The platform analyzes the applications } \\
\text { of the people who need credit, later } \\
\text { this information is presented to the } \\
\text { investors who decide whether to grant } \\
\text { the credit or not. A loan can be } \\
\text { financed by several investors. The } \\
\text { allocation of interest rates to lenders } \\
\text { depends on the level of default risk } \\
\text { and the term for which it is requested }\end{array}$ & Borrowers. & $\begin{array}{l}\text { Personal loans } \\
\text { with rates from } \\
8.90 \% \text { per annum. }\end{array}$ & $\begin{array}{l}\text { The investor } \\
\text { is charged 1\% } \\
\text { for each } \\
\text { payment } \\
\text { received }\end{array}$ \\
\hline
\end{tabular}


The service product is provided in a competitive way using specialized data and information from the customers and producers to increase quality and lower prices.

For the crowd-funding PF, the quality is a function of the investment firms' selection of projects and the choice and involvement of the investors made by the platform algorithm.

\section{Conclusions}

With the recent upsurge of the platform firms (which can be dated after 2008 with the introduction of the Apple's App Store), technology is generating an increase in socialization of production-in terms of workers and capital—but at the same time it is increasing the concentration of income without capital. The workers could also be consumers and the capital is originated through the sharing of private goods.

The main components of the systems for the PF are: (1) the internet operators, (2) the platform of which control the service, (3) the providers of the service through the app, (4) producer and consumer who enter into a relationship organized by the platform, (5) the inputs of production, and (6) other ancillary Apps.

There are two types of PF for the transportation market (private taxi service): (1) an oligopoly of consolidated PF, and (2) new entrants which are looking ahead trying innovations with their Apps to overcome the barriers of the network's positive effect in the big firms.

In the financial industry in Mexico, there is an oligopoly of the predominant big financial corporations, and then there is a marketing space for the new PF firms which are in the phase of introducing an alternative way of financing mainly for SMEs.

Until now there has been no clear way to regulate the PF in order to orient the competition between the traditional firms and the PF. Two criteria must be considered: (1) the stage of the evolution of the industry both the incumbent firms and the PF; (2) the nature of the industry market. These two aspects must defined in order to establish how much to support large distribution of income and benefits versus the monopolistic behavior (based on the economic network effect) of profits accumulated largely by the platform controller. The template is designed so that author affiliations are not repeated each time for multiple authors of the same affiliation. Please keep your affiliations as succinct as possible (for example, do not differentiate among departments of the same organization).

\section{References}

Botsman, R., \& Rogers, R. (2010). What's mine is yours: The rise of collaborative consumption. New York: Harper Collins Publishers.

Crowdfundinsider. (30 April 2016). Crowdfundinsider. Mexico prepares regulations for debt \& equity crowdfunding.

Retrieved from

http://www.crowdfundinsider.com/2016/04/84977-mexico-prepares-regulations-for-debt-equity-crowdfunding/

Desouza, K. C., Awazu, Y., Jha, S., Dombrowski, C., Papagari, S., Baloh, P., \& Kim, J. Y. (2008). Customer-driven innovation. Research-Technology Management, 51(3), 35-44.

Friedrich, R., Bartlett, C., Groene, F., \& Mialaret, N. (2013). Enabling the OTT revolution. New York, NY: Booz \& Company.

Fleisch, E. (2010). What is the Internet of Things? An economic perspective. Auto-ID Labs White Paper WP-BIZAPP-053. Zurich, Switzerland.

Glance, D. (5 January 2015). The conversation. How technology is changing language and the way we think about the world. Retrieved from https://theconversation.com/how-technology-is-changing-language-and-the-way-we-think-about-the-world-35856

Glückler, J., \& Hammer, I. (2011). A pragmatic service typology: Capturing the distinctive dynamics of services in time and space. The Service Industries Journal, 31(6), 941-957. 
Hamari, J., Sjöklint, M., \& Ukkonen, A. (2015). The sharing economy: Why people participate in collaborative consumption. Journal of the Association for Information Science and Technology. Wiley Online Library.

Hurst, D., Lesko, Z., \& Byrnes, K. (2014). Technology Enabled Services (TES): Rapidly growing service companies in a connected world. New York: AGC Partners.

Kodama, F. (September 2014). MOT intransition: From technology fusion to technology-service convergence. Technovation, 34(9), 505-512.

Manjoo, F. (23 March 2016). The Uber model, it turns out, doesn’t translate. The New York Times.

Matzler, K., Veider, V., \& Kathan, W. (2015). Adapting to the sharing economy. MIT Sloan Managment Review, 56(2), 71-77.

McKenna, B. (14 December 2015). Digital platform more than taxi service: Uber as app economy paradigm? Retrieved from http://www.computerweekly.com/opinion/Digital-platform-more-than-taxi-service-Uber-as-app-economy-paradigm

Morozov, E. (7 June 2015). The guardian. Where Uber and Amazon rule: Welcome to the world of the platform. Retrieved from https://www.theguardian.com/technology/2015/jun/07/facebook-uber-amazon-platform-economy

Omachonu, V. K., \& Einspruch, N. G. (2014). Innovation: Implications for goods and services. International Journal of Innovation and Technology Management, 7(2), 109-127.

Ortiz, A. (2016). Uber-and-cabify-in-Mexico. New service...same anticompetitive conduct. Retrieved from https://www.competitionpolicyinternational.com/assets/JR/Uber-and-Cabify-in-Mexico.pdf

Randhawa, K., \& Scerri, M. (2014). Service innovation: A review of the literature. In R. Agarwall, W. Selen, G. Ross, and G. Roy (Eds.), The handbook of service innovation (pp. 27-51) (1st ed.). London: Springer-Verlag.

Rapaccini, M., Saccani, N., Pezzot, G., Burger, T., \& Ganz, W. (2013). Service development in product-service systems: A maturity model. The Service Industries Journal, 33(3-4), 300-319.

Shapiro, C., \& Varian, H. R. (1999). Information rules. Boston Massachusetts: Havard Business School Press.

Solima, L., Della Peruta, M. R., \& Del Giudice, M. (2016). Object-generated content and knowledge sharing: The forthcoming impact of the Internet of Things. Journal of Knowelledge Economy, 7, 738-752.

Tullman, H. (29 March 2016). The five rules of Uber-ization. Retrieved from https://www.inc.com

Thrasyvoulou, $\quad$ X. (20 January 2015). Marketingprofs. Retrieved from http://www.marketingprofs.com/opinions/2015/26858/three-examples-of-uberization-done-right

Van Alstyne, M. W., Parker, G. G., \& Choudary, S. P. (April, 2016). Pipelines, platforms, and the new rules of strategy. Scale now trumps differentiation. Harvard Business Review, 94(4), 54-62.

Wikström, S. (1996). The customer as co-producer. European Journal of Marketing, 30(4), 6-19.

Witt, A., Suzor, N., \& Wikström, P. (2015). Regulating rides-sharing in the peer economy. Communication Research \& Practice, 1(2), 174-190.

Wardrop, R., Rosenberg, R., Zhang, B., Ziegler, T., Squire, R., Burton, J., Arenas Hernadez, E. J., \& Garvey, K. (2016). Breaking new ground. The Americas alternative finance. Cambridge: University of Cambridge Judge Business School. 